\title{
Enzymes in the rhizosphere of plants growing in the vicinity of the Polish Arctowski Antarctic Station.
}

\author{
A. Machuca $^{1 *}$, M. Cuba-Díaz ${ }^{1}$ and C. Córdova ${ }^{2}$ \\ ${ }^{1}$ Department of Plant Science and Technology, Campus Los Ángeles, and ${ }^{2}$ Department of Soils and \\ Natural Resources, Campus Chillán, Universidad de Concepción, Chile \\ *Corresponding author: angmachu@udec.cl
}

\begin{abstract}
In maritime Antarctica soil enzymes have been little researched, mainly in the rhizosphere of the only two vascular plants that grow there: Colobanthus quitensis and Deschampsia antarctica. This study evaluated the activities of hydrolytic enzymes $\beta$-glucosidase, phosphatase and urease in the rhizospheric soils of $C$. quitensis and D. antarctica from three different sites in the Polish Arctowski Station in Antarctica. The sensitivity to temperature changes of the enzymes was also evaluated using two incubation temperatures $\left(37\right.$ and $\left.12{ }^{\circ} \mathrm{C}\right)$. The highest activities related to the $\mathrm{C}$ and $\mathrm{P}$ cycles, $\beta$-glucosidase and acid phosphatase, respectively, were detected in the rhizospheric soils at the site with the greatest variety of plant cover. Urease activity, related to the $\mathrm{N}$ cycle, was high in two of the three sites, and the lowest activity was detected at the site where only $D$. antarctica was found. The activity of the enzymes decreased when the temperature of incubation was reduced, but the magnitude of the decrease depended on the enzyme. $\beta$-glucosidase was the most sensitive to temperature change, whereas urease was least affected. Therefore, temperature changes in rhizospheric soils could lead to changes in substrate degradation rates and consequently in the availability of nutrients $(\mathrm{C}, \mathrm{N}$ and $\mathrm{P})$ for $C$. quitensis and D. antartica in maritime Antarctica.
\end{abstract}

Keywords: Acid phosphatase, $\beta$-glucosidase, urease, Colobanthus quitensis, Deschampsia antarctica

\section{Introduction}

Colobanthus quitensis (Kunth) Bartl. (Caryophyllaceae) and Deschampsia antarctica Desv (Poaceae) are the only two vascular plants that have colonized the maritime Antarctic islands (Alberdi et al. 2002). These two species can live in association as a clump of grass with other organisms such as mosses and lichens, or as individuals, and thus the soil rhizosphere could be different. The associations with rhizospheric microorganisms (fungi and bacteria) and the presence of several soil enzymes can play an important role in the adaptation and survival of these plant species in extreme environments like Antarctica. For instance, some hydrolases in the 
soil like phosphatase, $\beta$-glucosidase and urease, are key to the biogeochemical cycles of $\mathrm{P}, \mathrm{C}$ and $\mathrm{N}$, respectively, contributing to plant nutritional status (Nannipieri et al. 2002; Ali et al. 2015; Gianfreda 2015). Soil enzymes have been used as indicators of microbial activity and the health and quality of soils, mainly in extreme environments, where they show the relative availability or limitation of energy or nutrient sources (Hopkins et al. 2008; Cowan et al. 2014). Most of the extracellular enzymes produced by Antarctic organisms are part of the pool of soil enzymes that efficiently catalyze multiple reactions at low temperatures, and are therefore involved in nutrient cycling. In recent years, the increase in global temperature has resulted in changes in the biological activity of the soils (Steinweg et al. 2013; Burns et al. 2013; Evans and Wallenstein 2014), and in the fragile ecosystems such as Antarctica, changes in temperature can produce changes in the enzymatic activities of soil, which in turn could affect the development of vascular plants and other types of vegetation.

The aim of this work was to assess the acid phosphatase, $\beta$-glucosidase and urease activities present in the rhizospheric soil of $C$. quitensis and D. antarctica growing at three different sites of maritime Antarctica. The responses of enzymes at two different soil incubation temperatures $\left(37\right.$ and $12{ }^{\circ} \mathrm{C}$ ) were also investigated to assess the changes in the catalytic activity of each enzyme for the effect of the temperature change. To the best of our knowledge, this is the first report about enzymes in the rhizosphere of vascular plants in maritime Antarctica.

\section{Materials and Methods.}

Soil samples were taken from the plant rhizosphere where the root system of clumps is extended up to around $10 \mathrm{~cm}$ depth. Three sites were sampled in the vicinity of the Polish Arctowski Station in Antarctica and each soil sample (AR1, AR2 and AR3) corresponded to a sample composed of rhizospheric soils from four plant clumps (C. quitensis plus $D$. antarctica or only $D$. antarctica, depending on the site). The main characteristics of the sites where the soils were collected are shown in Table 1. The sampling was done in the summer (January 2011) when the snow had melted. After collection, the samples were transported at low temperature $\left(5^{\circ} \mathrm{C}\right.$ approx.) to the laboratory where they were stored at $4{ }^{\circ} \mathrm{C}$ for about two weeks until analysis of enzyme activities. The soil samples were air-dried and sieved through $2 \mathrm{~mm}$ mesh to determine potential activities of $\beta$-glucosidase (Eivazi and Tabatabai 1988), acid phosphatase (Tabatabai and Bremner 1969), and urease (Kandeler et al. 1999). The analytical determinations were carried out in triplicate and enzyme activities were expressed as $\mu \mathrm{mol} \mathrm{g} \mathrm{g}^{-1}$ dried soil $\mathrm{h}^{-1}$. Soil samples were incubated at $37^{\circ} \mathrm{C}$ a standard temperature for enzyme soil assays, and at $12{ }^{\circ} \mathrm{C}$, to explore the effect of temperature on the catalytic rate of the enzymes.

Table 1. Main characteristics of the Antarctic sites where the rhizospheric soils were collected

\begin{tabular}{|c|c|c|c|}
\hline & $\mathrm{AR} 1$ & AR2 & AR3 \\
\hline Location & $\mathrm{S}^{\prime} 62^{\circ} 09^{\circ} 44.6^{\prime \prime} ; \mathrm{WO}^{\circ} 28^{\prime} 16.7^{\prime \prime}$ & $\mathrm{S}^{\prime} 2^{\circ} 09^{\prime} 32.0^{\prime \prime} ; \mathrm{WO} 58^{\circ} 28^{\prime} 10.8^{\prime \prime}$ & $\mathrm{S}^{\prime} 62^{\circ} 09^{\prime} 32.7^{\prime \prime} ; \mathrm{WO} 58^{\circ} 28^{\prime} 13.6^{\prime \prime}$ \\
\hline Site & Site on a hillside, distant from & Stony soil around the Arctowski & Stony soil around the Arctowski \\
\hline description & $\begin{array}{l}\text { Arctowski Station. Peat soil appearance } \\
\text { with abundant vegetation. No human } \\
\text { activity; intense seabird activity. }\end{array}$ & $\begin{array}{l}\text { Station and near the sea, with patchy } \\
\text { vegetation distribution. Intense } \\
\text { human activity; moderate penguin } \\
\text { activity. }\end{array}$ & $\begin{array}{l}\text { Station and near the sea, with } \\
\text { patchy vegetation distribution. } \\
\text { Intense human activity. }\end{array}$ \\
\hline $\begin{array}{l}\text { Vegetation } \\
\text { cover }\end{array}$ & $\begin{array}{l}\text { C. quitensis (abundant) }+ \\
\text { D. antarctica }(\text { scarce })+\text { mosses }+ \\
\text { lichens. }\end{array}$ & $\begin{array}{l}\text { C. quitensis }+ \text { D. antarctica }+ \\
\text { mosses. }\end{array}$ & D. antarctica. \\
\hline
\end{tabular}




\section{Results and Discussion}

The three AR sites showed different characteristics in the type and abundance of vegetation, with AR1 and AR2 being the most diverse in terms of species types, mainly AR1 (Table 1). At different sites the plant cover might be influencing the structure and size of the rhizospheric microbial communities, which in turn are responsible for the different extracellular enzyme patterns present in soils (Yergeau and Kowalchuk, 2008; Zeglin et al. 2009; Gianfreda 2015). Since the sample size from the rhizosphere was very small, it was not possible to analyze the chemical composition of the soil; however, previous bulk samples taken from AR1 showed high organic matter content (O.M. 9.67\%), P-Olsen (53.1 mg. Kg-1), and low pH (5.1) (Cuba et al., 2010).

In terms of enzymatic activities in the rhizosphere soils of the AR sites, the highest activities of acid phosphatase and $\beta$-glucosidase were detected in soils from AR1 (Figure 1A and B), the site with the greatest variety in the vegetation cover and the farthest from the Arctowski Station and therefore no human traffic. By contrast, the urease activity was high in AR1 and AR2, and very low at the site where only $D$. antarctica was found (Figure 1C). The $\beta$-glucosidase showed the greatest variability between sites and the lowest activity values were detected at AR2 (Figure 1B).

The abundant plant cover and high activity of seabirds at AR1 may be the reason for the high contents of O.M., $\mathrm{P}$ and $\mathrm{N}$ detected in previous studies (Cuba et al., 2010), which stimulates some enzymes such as urease, xylanase and phosphatases (Beyer et al. 2000; Tscherko et al. 2003). The urease in the soil is of microbial and plant origin, but it can also come from seabird and penguin excrement (Tscherko et al. 2003). Although the rhizospheric soils at AR2 and AR3 were not chemically analyzed, they would probably have lower nutrient and O.M. contents than AR1 due to the patchy colonization of plant growth and the absence of seabird activity contrasting with intense levels of human disturbance (Table 1). This could be the reason for the low levels of $\beta$-glucosidase found at AR2 and AR3 and low level of urease at AR3 (Figure 1B and $1 \mathrm{C}$, respectively). Additionally, D. antarctica was found only in AR3 and this may also be related to the low levels of urease in this rhizospheric soil. On the other hand, the presence of some penguin excrement would explain the level of urease at AR2 (Figure 1C). $\beta$-glucosidase belongs to the enzyme complex produced mainly by fungi and bacteria, and it hydrolyses cellulose, contributing to the input of organic $\mathrm{C}$ in soils; it is positively correlated with high contents of O.M., low $\mathrm{pH}$ and the presence of vascular plants (Hopkins et al. 2008; Zeglin et al. 2009). Apparently the levels of acid phosphatase and urease in the rhizospheric soils were not as affected by the different characteristics of the AR sites than $\beta$-glucosidase. On the other hand, the values of acid phosphatase, $\beta$-glucosidase and urease activity determined under standard conditions $\left(37^{\circ} \mathrm{C}\right)$ are within the ranges reported by Trasar-Cepeda et al. $(2008 \mathrm{a}, \mathrm{b})$ for a series of temperate climate soils under agricultural or forest management.

The influence of temperature on enzyme activity revealed that the decrease in incubation temperature from $37^{\circ}$ to $12{ }^{\circ} \mathrm{C}$ reduced the enzyme reaction rate as expected. However, the magnitude of this effect depended on the type of enzyme. The enzyme most sensitive to the temperature change was $\beta$-glucosidase (68-78\% reduction with temperature decrease) and the least sensitive was urease (55-56\% reduction). It has been observed in Alpine and Arctic tundra soils that $\mathrm{C}$ mineralization is more sensitive to low temperatures than $\mathrm{N}$ mineralization, which is a result of different sensitivities of the enzymes participating in the cycles of these elements (Koch et al. 2007; Wallenstein et al. 2009; 2011; Jing et al. 2014). Our results suggest that at low temperatures $\left(12^{\circ} \mathrm{C}\right)$ or even lower (like those found in Antarctica), the enzymes must be acting at very low rates, resulting in a slow hydrolysis of the components of the O.M. in rhizospheric soils. 
Therefore, in a global warming scenario an increase in enzyme activities related to the cycles of $\mathrm{N}, \mathrm{P}$ and $\mathrm{C}$ is to be expected in maritime Antarctic soils, which may lead to changes in the availability of nutrients in the rhizospheric soils of $C$. quitensis and D. antarctica.
This is a first approach to explore the sensitivity to temperature changes in the reactions catalyzed by acid phosphatase, $\beta$-glucosidase and urease from rhizospheric maritime Antarctic soils.
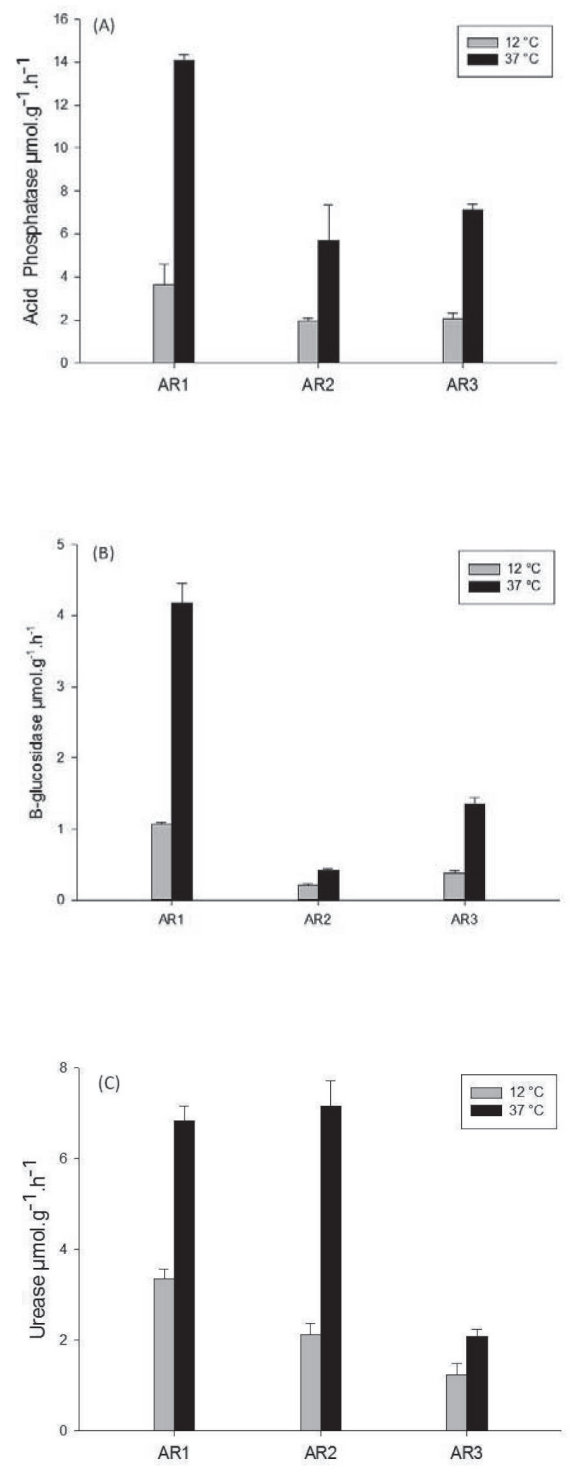

Figure 1. Potential acid phosphatase (A), $\beta$-glucosidase (B) and urease (C) activities $\left(\mu \mathrm{mol} \mathrm{g}^{-1}\right.$ soil.h $\left.^{-1}\right)$ in rhizospheric soils from different Antarctic (AR) sites containing vascular plants, assayed at $12^{\circ} \mathrm{C}(\square)$ and $37^{\circ} \mathrm{C}(\square)$. The means ( \pm SE) of enzyme activities are shown. 


\section{Conclusions}

The highest activities of $\beta$-glucosidase and acid phosphatase were detected in the rhizospheric soils at the site with the greatest variety of plant cover (AR1). Urease activity was high in two of the three sites, and the lowest activity was detected at the site where only $D$. antarctica was found (AR3). The activity of the enzymes decreased when the temperature of incubation was reduced, but the magnitude of the decrease depended on the enzyme. $\beta$-glucosidase related to $\mathrm{C}$ cycle, was the most sensitive to temperature change, whereas urease related to $\mathrm{N}$ cycle, was least affected.

\section{Acknowledgments}

We wish to thank Ms. I. Cid and Mr. D. Chávez for technical support, and the Instituto Antártico Chileno (INACH) and Arctowski Polish Station for their logistical support. This research was granted by INACH (Project T_03-09).

\section{References}

Alberdi, M., Bravo, L.A., Gutiérrez, A., Gidekel, M., Corcuera, L.J. 2002. Ecophysiology of Antarctic vascular plants. Physiol. Plant. 115, 479-486.

Ali, R., Ingwersen, J., Demyan, M. Funkuin, Y., Wizemann, H., Kandeler, E., Poll, C. 2015. Modelling in situ activities of enzymes as a tool to explain seasonal variation of soil respiration from agro-ecosystems. Soil Biol. Biochem. 81, 291-303.

Beyer, L., Bolter, M., Seppelt, R.D. 2000. Nutrient and thermal regime, microbial biomass, and vegetation of Antarctic soils in the Windmill Islands Region of East Antarctica (Wilkes Land). Arct. Antarc. Alp. Res., 32, 30-39.
Burns, R., De Forest, J., Marxsen, J., Sinsabaugh, R., Stromberger, M., Wallenstein, M., Weintraub, M., Zoppini, A. 2013. Soil enzymes in a changing environment: current knowledge and future directions. Soil Biol. Biochem. 58, 216234.

Cowan, D.A., Makhalanyane1, T.P., Dennis, P.G., Hopkins, D.W. 2014. Microbial ecology and biogeochemistry of continental Antartic soils. Front. Microbiol. 5, 1-10.

Cuba, M., Cid, I., Machuca, A. 2010. Characterization of Antarctic and continental soils where Colobanthus quitensis populations develop. 4th. Open Science Conference CD-ROM, 183, 1.

Eivazi, F., Tabatabai, M.A. 1988. Glucosidases and galactosidases in soils. Soil Biol. Biochem. 20, 601-606.

Evans, S.E., Wallenstein, M.D. 2014. Climate change alters ecological strategies of soil bacteria. Ecol. Lett. 17, 155-164.

Gianfreda L. 2015. Enzymes of importance to rhizosphere processes. J. Soil Sci. Plant Nutr. Disponible en:http://dx.doi.org/10.4067/S071895162015005000022 .

Hopkins, D.W., Sparrow, A.D., Shillam, L.L., English, L.C., Dennis, P.G., Novis, P., Elberling, B., Gregorich, E.G., Greenfield, L.G. 2008. Enzymatic activities and microbial communities in an Antarctic dry valley soil: responses to $\mathrm{C}$ and N supplementation. Soil Biol. Biochem. 40, 21302136.

Jing, X., Wang, Y., Chung, H., Mi, Z., Wang, S., Zeng, H., He, J. 2014. No temperatura acclimation of soil extracellular enzymes to experimental warming in an alpine grassland ecosystem on the Tibetan plateau. Biogeochem. 117, 39-54. 
Kandeler, E., Stemmer, M., Klimanek, E.M. 1999. Response of soil microbial biomass, urease and xylanase within particle size fraction to long-term soil management. Soil Biol. Biochem. 31, 261273.

Koch, O., Tscherko, D., Kandeler, E. 2007. Temperature sensitivity of microbial respiration, nitrogen mineralization, and potential soil enzyme activities in organic alpine soil. Glob. Biogeochem. Cycles. 21, GB4017, 10.1029/2007GB002983.

Nannipieri, P., Kandeler, E., Ruggiero, P. 2002. Enzymes activities and microbiological and biochemical processes in soil. In: Burns, R.G. and Dick, R.P., eds. Enzymes in the Environment: Activity, Ecology, and Applications. New York: Marcel Dekker, 1-33.

Steinweg, J.M., Dukes, J.S., Paul, E.A., Wallenstein, M.D. 2013. Microbial responses to multi-factor climate change: effects on soil enzymes. Front. Microbiol. 4, 146-157.

Tabatabai, M.A., Bremner, J.M. 1969. Use of p-nitrophenyl phosphate for assay of soil phosphatase activity. Soil Biol. Biochem. 1, 301307.

Trasar-Cepeda, C., Leirós, M.C., Gil-Sotres, F. 2008a. Hydrolytic enzymes activities in agricultural and forest soils. Some implications for their use as indicators of soil quality. Soil Biol. Biochem. 40, 2146-2155.
Trasar-Cepeda, C., Leirós, M.C., Gil-Sotres, F. 2008b Modification of biochemical properties by soil use. J. Soil Sc. Plant Nutr. 8, 53-60.

Tscherko, D., Bolter, M., Beyer, L., Chen, J., Elster, J., Kandeler, E., Kuhn, D., Blume, H.P. 2003. Biomass and enzyme activity of two soil transects at King George Island, maritime Antarctica. Arct. Antarc. Alp. Res. 35, 34-47.

Wallenstein, M.D., McMahon, S.K., Schimel, J.P. 2009. Seasonal variation in enzyme activities and temperature sensitivities in Arctic tundra soils. Glob. Chang. Biol. 15, 1631-1639.

Wallenstein, M.D., Allison, S.D., Ernakovich, J., Steinweg, J.M., Sinsabaugh, R. 2011. Controls on the temperature sensitivity of soil enzymes: a key driver of in situ enzyme activity rates. In: Shukla, G. and Varma, A., eds. Soil Enzymology. Soil Biology. New York: Springer, 245-258.

Yergeau, E., Kowalchuk, G.A. 2008. Responses of Antarctic soil microbial communities and associated functions to temperature and freezethaw cycle frequency. Environ. Microbiol. 10, 2223-2235.

Zeglin, L.H., Sinsabaugh, R., Barrett, J.E., Gooseff, M.N., Takacs-Vesbach, C.D. 2009. Landscape distribution of microbial activity in the McMurdo Dry Valleys: linked biotic processes, hydrology, and geochemistry in a cold desert ecosystem. Ecosystems. 12, 562-573. 